\title{
Perspektif Kriminologi Terhadap Tindak Pidana Narkotika Yang Dilakukan Oleh Anak
}

\author{
Sarah Widyaristanty ${ }^{1}$ \\ Universitas Trunojoyo Madura \\ sarahristanty@gmail.com \\ Stifani Theresa Berliana ${ }^{2}$ \\ Universitas Trunojoyo Madura
}

\begin{abstract}
ABSTRAK
Dalam era 4.0 ini penyalahgunaan narkotika tidak hanya dialami oleh kalangan orang dewasa saja, akan tetapi penyalahgunaan narkotika pada saat ini juga sudah dialami oleh anak-anak. Akibat dari adanya penyalahgunaan narkotika yang terjadi pada anak ini adalah dapat mengakibatkan terancam-nya masa depan anak. Dari adanya hal tersebut maka penelitian ini dimaksudkan agar anak yang melakukan tindak pidana penyalahgunaan narkotika tidak melakukan hal yang sama dengan cara mengetahui faktor apa saja yang kemungkinan terjadi sehingga anak melakukan tindak pidana penyalahgunaan narkotika serta bagaimana upaya yang dapat dilakukan dalam menangani anak yang terlibat dalam penyalahgunaan narkotika. Penelitian ini dilakukan dengan menggunakan metode normatif. Yang mana penelitian ini diperoleh dari penelitian kepustakaan yang menjawab permasalahan hukum yang akademis dan praktis, baik yang bersifat asas-asas hukum, norma-norma hukum yang hidup dan berkembang di masayarakat, maupaun yang berkenaan dalam kenyataan hukum di masyarakat. Kesimpulan dari penelitian ini adalah adanya penyalahgunaan narkotika yang dilakukan oleh anak disebabkan oleh faktor internal serta faktor eksternal. Dan untuk upaya penanggulangan yang dapat diterapkan sebisa mungkin dilakukan secara non penal hal ini dilakukan untuk melindungi masa depan anak tersebut. Selain itu pencegahan yang paling efektif agar anak tidak terlibat dalam tindak pidana penyalahgunaan narkotika adalah pengawasan orang tua.
\end{abstract}

\section{Kata Kunci : Penyalahgunaan Narkotika, Kriminologi, Anak}

\begin{abstract}
In this era of 4.0, narcotics abuse is not only experienced by adults, but nowadays narcotics abuse has also been experienced by children. The result of the abuse of narcotics that occurs in this child is that it can threaten the child's future. From this, this research is intended so that children who commit criminal acts of narcotics abuse do not do the same thing by knowing what factors are likely to occur so that children commit crimes of narcotics abuse and how efforts can be made in dealing with children who are involved in abuse. Narcotics. This research was conducted using the normative method. Where this research is obtained from literature research that answers academic and practical legal problems, both in the form of legal principles, legal norms that live and develop in society, as well as those relating to legal realities in society. The conclusion of this study is the existence of narcotics abuse committed by children is caused by internal factors as well as external factors. And for countermeasures that can be implemented as non-penal as possible, this is done to protect the child's future. Besides that, the most effective prevention so that children are not involved in criminal acts of narcotics abuse is parental supervision.
\end{abstract}

Keywords: Narcotics Abuse, Criminology, Children 


\section{PENDAHULUAN}

Negara Indonesia kasus narkotika sudah sangat merajalela hingga kasusnya dari tahun ke tahun selalu meningkat pesat, Bahwa sudah banyak orang yang tersandung atau terjerumus dengan Bahan Haram atau biasa disebut dengan narkotika. Yang menjadi perhatian dari kasus Tindak Pidana Narkotika ini adalah pelakunya yang tidak hanya dilakukan oleh orang dewasa saja tetapi juga oleh orang yang belum dewasa atau biasa disebut dengan anak-anak. Sehingga untuk pengaturannya sendiri memiliki hukum yang secara khusus menangani Hukum Anak terutama di Indonesia. "Menurut Darwan Prinst hukum anak adalah sekumpulan peraturan hukum, yang mengatur tentang anak. Adapun hal-hal yang diatur dalam hukum anak itu meliputi sidang pengadilan anak, anak sebagai pelaku tindak pidana, anak sebagai korban tindak pidana, kesejahteraan anak, hak-hak anak, kedudukan anak dan lain sebagainya ${ }^{1}$." Yang terkodifikasi dalam Undang-Undang Nomor 11 tahun 2012 tentang Sistem Peradilan Pidana Anak yang (Selanjutnya disebut Undang-Undang SPPA).

\section{Menurut Undang-Undang SPPA} menyatakan batasan usia untuk orang belum dewasa atau anak-anak adalah yang belum berusia 18 tahun maka semisal terdapat kasus pada hari sabtu tanggal 17 Agustus 2020 Si A melakukan tindak pidana dan belum berusia 18 Tahun dan tertangkap oleh kepolisian pada hari minggu 18 Agustus 2020 si A berusia 18 Tahun. maka tetap kasus si A masuk ranah pidana anak

1 Darwan Prinst, "Hukum Anak Indonesia", Bandung, PT. Citra Aditya Bakti, 2003. hlm 1 dan diadili dengan menggunkan sistem peradilan anak.

Sebagai contoh kasus yaitu dilansir dari “Kompas.com pada tanggal 6 Januari 2020 di Denpasar Bali empat anak berinisial AB (16), DB (13), LK (4), dan SJ (16) yang keempatnya belum dewasa atau belum ada yang berusia 18 tahun. ditangkap oleh Satuan Reserse Narkoba (Satres) Polresta Denpasar karena menjadi kurir narkoba jenis sabu dan ekstasi. Dalam penangkapan tersebut, turut diamankan barang bukti berupa sabu 2,17 gram dan 78 butir ekstasi. Mereka menerima narkotika yang sudah dibugkus dan tinggal menunggu perintah untuk ditempelkan di lokasi yang ditentukan. Dalam aksinya, anak-anak ini diupah Rp 100.000 sekali tempel dan dijanjikan bonus memakai sabu-sabu. Kini, pihak kepolisian masih memburu Dogler sebagai dalang utama. Diduga, barang-barang tersebut didatangkan dari Jawa Timur melalui jalur darat. Menurut Rudi keempat anak-anak itu mau menjadi kurir karena faktor ekonomi ${ }^{2}$

Bahwa melihat pelaku atau pengguna adalah anak-anak merupakan sebuah masalah besar bagi suatu negara terutama Negara Indonesia karena anak-anak merupakan suatu aset negara karena mereka adalah generasi penerus bangsa di masa depan untuk terus menjalankan suatu roda negara. yang menjadi perhatian adalah pelakunya adalah anak-anak sekolahan ada yang dari SMP hingga SMA. Hal ini mungkin bisa dikarenakan Kondisi emosional

2Berita dikutip dari :
$\frac{\text { https://denpasar.kompas.com/read/2020/ }}{\text { 01/15/12570781/miris-4-anak-di-bawah- }}$
$\frac{\text { umur-edarkan-narkoba-bonusnya-dikasih- }}{\text { sabu?page=all (Diakses pada 30 desember }}$
2020 Pukul 23.58 WIB)

Universitas Trunojoyo Madura 
anak-anak masih dalam keadaan labil dan anakanak pada usia SMP atau SMA mereka sedang proses dalam mencari jati dirinya sehingga sangat mudah sekali untuk mereka senang mencoba hal-hal baru dan sangat mudah sekali terpengaruh baik itu positif maupun negatif, mungkin hal inilah yang menyebabkan meningkatnya kasus penyalahgunaan narkotika dikalangan siswa atau anak-anak. Karena rasa penasarannya ini membuat mereka tidak peduli dengan keadaan diri mereka sendiri tentang efek apa yang ditimbulkan setelah melakukan sesuatu hal-hal yang baru dan menurut mereka menantang untuk dilakukan, sehingga betapa pentingnya suatu edukasi sejak kecil atau sejak dini tentang pentingnya menjaga diri, bisa membedakan hal-hal yang positif dan negatif, serta menjalani hidup sesuai norma-norma yang berlaku sehingga anak-anak dari kecil atau dari dini akan mengerti dan paham antara yang benar dan salah. Padahal seharusnya anak-anak itu menikmati masa muda mereka untuk belajar menuntut ilmu dan bermain, namun pada faktanya anak-anak zaman sekarang tidak kalah bersaing dengan dengan orang-orang dewasa untuk melakukan tindak pidana.

Sehingga yang menjadi sorotan atau pembahasan disini adalah tentang bagaimana sebab musabab anak-anak ataupun remaja dapat mengenal bahkan mengonsumsi narkoba, padahal kita mengerti bahwa narkoba memiliki kandungan yang sangat berbahaya bahkan haram hukumnya bila dikonsumsi terlebih jika dikonsumsi oleh anak-anak ataupun remaja. Narkoba juga termasuk kedalam kategori kejahatan luar biasa (extraordinary crime). Hal ini dikarenakan peredaran dan dampak negatif dari narkoba itu sendiri yang berbahaya di Indonesia Tindak Pidana Narkotika sudah diatur dalam Undang-Undang Nomor 35 Tahun 2009 tentang Narkotika yang (selanjutnya disebut dengan Undang-Undang Narkotika). Akan tetapi terdapat pengecualian jika penyalahgunaan narkotika tersebut terjadi pada anak-anak yang belum dewasa atau belum berusia 18 tahun maka delik narkotika ini masuk kedalam ranah pidana anak dan diproses menurut sebagaimana yang diatur dalam Undang-Undang SPPA.

Penyalahgunaan narkotika merupakan tindakan yang menyimpang dari norma-norma yang berlaku di masyarakat salah satunya adalah norma agama. Anak yang menggunakan narkoba menunjukkan perilaku yang tidak berpegangan pada norma agama. Norma agama berpengaruh bagi perkembangan anak, anak yang berkembang tanpa agama yang kuat akan menjadi pribadi yang mudah terpengaruh terhadap hal-hal negatif, selain itu penyalahgunaan narkotika juga merupakan perbuatan yang menyimpang dari norma hukum. Terdapat banyak penyebabpenyebab atau faktor-faktor yang mengakibatkan seorang anak dapat melakukan tindak pidana narkotika, sehingga kita harus mengetahui faktor-faktor yang menyebabkan tindak pidana narkotika yang dilakukan oleh anak-anak dapat terjadi, sehingga setelah mengetahui yang menjadi faktor penyebab maka harus terdapat solusi-solusi dalam memecahkan permasalahan akibat faktor-faktor penyebab yang dialami oleh anak anak atau remaja yang terlibat langsung dalam kasus tindak pidana narkotika ini apabila terdapat suatu solusi maka tinggal bagaimana caranya mengimplemen-tasikannya. Jika ditinjau dari sisi kriminologi, maka dalam penelitian ini, 
dapat menggunakan beberapa teori kriminologi diantaranya yakni teori differential association, teori kontrol sosial dan teori labeling. Ketiga teori tersebut digunakan sebagai pisau analisis dalam penelitian ini.

Untuk mengetahui delik yang dilakukan oleh anak dalam menggunakan narkotika, maka diperlukan sebuah perhatian khusus dikalangan penegak hukum yang mempunyai kewenangan terutama aparat penegak hukum dan masyarakat agar dapat berusaha keras dengan segala daya kemampuan yang dimiliki untuk menanggulangi kenakalan anak menggunakan narkotika ${ }^{3}$.

\section{METODE PENELITIAN}

Dalam penelitian ini menggunakan-metode normatif. Metode normatif ini akan diimplementasikan dengan cara menganalisis peraturan perundang-undangan yang ada serta melakukan kajian kepustakaan yang bersumber dari buku, jurnal ataupun sumber yang lainnya.

\section{HASIL DAN PEMBAHASAN}

\section{Faktor-Faktor Yang Dapat Mempengaruhi Anak Melakukan Tindak Pidaana Penyalahgunaan Narkotika}

Berbicara masalah kriminologi, Sutherland and Cressy berpendapat bahwasannya kriminologi merupakan suatu ilmu pengetahuan yang menjelasakan bahwa kejahatan merupakan suatu gejala sosial serta mengemukakan tentang ruang lingkup

3 Fadiah Idzni, "Kajian Kriminologi Terhadap Anak Yang Melakukan Tindak Pidana Narkotika (Studi Kasus di Sat. Res Narkoba Polrestabes Medan)" Skripsi, Medan: Universitas Muhammadiyah Sumatera Utara, 2019. hlm 4 kriminologi yang mencakup proses perbuatan hukum dan reaksi sosial atas pelanggaran suatu hukum. Dalam hal ini apabila anak melakukan tindak pidana narkotika maka perlu kirannya sebelum anak tersebut mempertanggung jawabkan perbuatannya melalui jalur penal atau proses penyelesaian hukum sesuai dengan Kitab Undang-Undang Hukum Acara Pidana yang (selanjutnya disebut sebagai (KUHAP) aparat penegak hukum harus mengupayakan penyelesaian perkara melalui jalur non penal. Jalur non penal yang dapat dilakukan untuk pertanggungjawaban anak yang melakukan tindak pidana adalah proses diversi. ${ }^{4}$

Mengingat nak merupakan generasi emas penerus bangsa yang mana didalamnya terdapat benih yang merupakan cikal bakal dalam mewujudkan cita-cita bangsa. Dalam Pasal 1 angka 1 Undang-Undang Nomor 23 Tahun 2003 tentang Perlindungan Anak Jo. Undang-Undang Nomor 35 Tahun 2014 tentang Perubahan Atas Undang-Undang Nomor 23 Tahun 2003 Tentang Perlindungan Anak yang (selanjutnya disebut UndangUndang Perlindungan Anak) menjelaskan bahwa anak merupakan seseorang yang belum berusia 18 (delapan belas) tahun dan termasuk anak yang masih dalam kandungan.

Seiring dengan berkembangnya zaman, anak dapat dengan mudah mendapatkan suatu informasi sehingga hal ini menyebabkan adanya kenakalan pada anak jika informasi tersebut tidak disaring dengan baik. Salah satu persoalan yang sering terjadi terkait

\footnotetext{
${ }^{4}$ Lihat Pasal 1 angka 7 UU SPPA
} 
kenakalan pada anak adalah anak tersebut melakukan tindak pidana penyalahgunaan narkotika.

Narkotika sendiri merupakan suatu barang yang akan menyebabkan rusaknya generasi bangsa yang akan datang, hal ini terlihat dari arti narkotika sendiri yang dijelaskan dalam Pasal 1 angka 1 UndangUndang Narkotika yang menjelaskan bahwa narkotika sendiri adalah suatu zat atau obat yang berasal dari tanaman atau bukan tanaman, baik sintetis maupun semisintetis, yang menyebabkan penurunan atau perubahan kesadaran, hilangnya rasa, mengurangi sampai menghilangkan rasa nyeri dan dapat menimbulkan ketergantungan yang dibedakan kedalam golongan-golongan yang terdapat pada lampiran undang-undang narkotika. Dalam Undang-Undang Narkotika, Narkotika dibagi menjadi tiga golongan ${ }^{5}$, yaitu :

1. Narkotika Golongan I merupakan golongan narkotika yang hanya digunakan untuk pengembangan ilmu pengetahuan saja serta tidak digunakan dalam terapi atau pengobatan dalam dunia kesehatan. hal ini dikarenakan narkotika golongan I ini menyebabkan ketergantungan yang sangat tinggi. Contoh dari narkotika golongan I ini adalah Tanaman Papaver Somniferum $L$

2. Narkotika Golongan II merupakan narkotika yang dapat dijadikan sebagai bahan untuk terapi atau pengobatan dalam

5 Lihat Pasal 6 ayat (1) Undang-Undang Nomor 35 Tahun 2009 tentang Narkotika. dunia kesehatan. akan tetapi penggunaan narkotika golongan II dalam dunia kesehatan dilakukan sebagai pilihan terakhir dikarenakan berpotensi tinggi menyebabkan ketergantungan. Selain digunakan dalam dunia kesehatan, narkotika golongan II ini juga digunakan untuk pengembangan ilmu pengetahuan. Contoh dari narkotika golongan II ini adalah Alfasetilmetadol.

3. Narkotika Golongan III merupakan narkotika yang memiliki manfaat pada pengobatan serta narkotika golongan III ini banyak digunakan untuk terapi atau pengobatan yang lainnya dikarenakan potensi ketergantungannya rendah. Selain itu narkotika golongan III ini juga dapat digunakan untuk penelitian dan pengembangan ilmu pengetahuan. Contoh dari narkotika golongan III ini adalah Asetildihidrokodeina. Pada tahun 2019 di Kota Surabaya tercatat sebanyak 72 kasus penyalahgunaan narkotika yang dilakukan oleh anak-anak. Berikut adalah table jumlah penyalahgunaan narkotika yang dilakukan oleh anak :

\begin{tabular}{|l|l|}
\hline Jumlah Kasus & 72 Kasus \\
\hline Jenis Kelamin & $\begin{array}{l}\text { 68 Laki-laki } \\
4 \text { Perempuan }\end{array}$ \\
\hline Rata-Rata Usia & $13-17$ Tahun \\
\hline
\end{tabular}

Tingginya angka tindak pidana penyalahgunaan narkotika yang dilakukan oleh anak disebabkan karena kelalaian serta pengabaian sosial, sehingga anak dapat mengembangkan 
tingkah laku yang menyimpang dari norma-norma yang ada 6 . Dalam ilmu kriminologi, tindak pidana narkotika dapat dikatakan sebagai suatu kejahatan yang tidak ada korbannya (crime without victim). Hal ini dikarenakan dalam tindak pidana narkotika, korban yang dimaksud adalah dirinya sendiri sehingga pelaku tindak pidana narkotika juga merupakan seorang korban dari tindak pidana tersebut ${ }^{7}$. Jika dilihat dari segi kriminologi, maka permasalahan semacam ini dapat dianalisis dengan beberapa teori. Teori yang pertama yakni teori differential association. Teori ini merupakan teori yang dikemukakan oleh Edwin H. Sutherland pada tahun 1934. Teori ini menjelaskan bahwasannya setiap orang akan mengakui pola-pola perilaku yang nantinya dapat dilaksanalan yang bersal dari kelompok-kelompok serta struktur masyarakat yang ada. Sehingga dalam hal ini akan mempengaruhi kepribadian setiap manusia. Jika dikaitkan dengam penelitian ini, maka anak yang

6 Inda Kumala Sari M, 2017, Analisis Tetang Penyalahgunaan Narkotika Dikalangan Siswa Ditinjau Dari Segi Kriminologi, Jurnal hukum kaidah, Vol. 18, No.1, ISSN online: 2613-9340, ISSN offline 1412-1255. hlm. 18

7 Besse Patmawanti dan Kiki Yulianda, 2020, Tinjauan Kriminologi Tindak Pidana Narkotika Yang Dilakukan Oleh Anak Di Wilayah Hukum Polres 50 Kota, UNES Law Review, Volume 3, Issue 1, E-ISSN: 2622-7045, P-ISSN: 2654-3605. hlm 23. melakukan tindak pidana narkotika berawal dari mengikuti pola pola kehidupan yang ada di lingkungan sekitarnya, sehingga secara tidak langsung kepribadian sang anak terbentuk dari sana.

Teori yang kedua yakni teori kontrol sosial. Teori ini merupakan suatu teori yang berusaha menjawab mengapa orang melakukan kejahatan. Teori kontrol tidak lagi mempertanyakan mengapa orang melakukan kejahatan, tetapi mempertanyakan mengapa tidak semua orang melanggar hukum atau mengapa orang taat terhadap hukum ${ }^{8}$. Apabila dikaitkan dengan tindak pidana narkotika yang dilakukan oleh anak sudah jelas jika pasti seseorang anak telah memutuskan untuk memilih apakah ia akan melakukan tindak pidana narkotika ataukah memilih untuk menaati peraturan? Saat anak memilih tindak pidana narkotika dia sudah ada pengaruh sebab-mushabab mengapa ia memutuskan untuk memilih itu.

Teori yang ketiga yakni teori Label Menurut Becker, kejahatan terbentuk karena aturan-aturan lingkungan, sifat individual, dan reaksi masyarakat terhadap kejahatan. Telah menjadi kesepakatan para penganut teori label, bahwa proses pemberian label merupakan penyebab seseorang

8 Fadiah Idzni, Op.cit, Hlm. 30.

Universitas Trunojoyo Madura 
untuk menjadi jahat. ${ }^{9}$ Apabila dikaitkan dengan tindak pidana narkotika yang dilakukan oleh anak, bisa saja karena dilingkungan anak tersebut di cap oleh lingkungan sekitar sebagai anak yang nakal dan berandalan jalan mengakibatkan dia malah menjadi lebih nakal dan berani melakukan tindak pidana narkotika karena labelnya yang dicap oleh lingkungan sekitarnya. Dari berbagai teori yang ada, maka tindak pidana penyalahgunaan narkotika yang dilakukan oleh anak disebabkan karena adanya beberapa faktor. Faktor-faktor tersebut dapat dibagi kedalam 2 golongan yakni faktor internal dan faktor eksternal ${ }^{10}$.

\section{a. Faktor Internal}

Faktor internal merupakan suatu faktor yang mana berasal dari dalam diri anak tersebut. Berikut adalah contoh dari faktor internal yang dapat menyebabkan anak melakukan tindak pidana penyalahgunaan narkotika:

1) Faktor Religiositas

Religiositas merupakan suatu pengabdian terhadap agama. Seiring perkembangan zaman, nilai-nilai agama mulai menghilang. sehingga pondasi seorang anak dalam menjalankan hidupnya kurang kuat.

${ }^{9}$ Ibid

10 Henny Saida Flora, 2017, Legal Protection Of Children In the Criminal Act Of Narcotics, International Journal Of Business, Economics and law, Vol. 14, Issue 4, December, ISSN 2289-1552. hlm. 26.
Dan tentu saja hal ini membuat seorang anak mudah terpengaruh.

1) Faktor Individu Atau Kepribadian

Jika seorang anak memiliki kepribadian yang mudah terpengaruh oleh lingkungannya atau orang yang ada disekitarnya, serta tidak memiliki sikap yang tegas maka kemungkinan besar anak tersebut nanti-nya akan mudah terpengaruh terhadap hal-hal yang dilarang oleh norma-norma yang ada apabila anak tersebut pergaulannya salah dan tidak ada pengawasan khusus yang dilakukan oleh orang tua. Salah satunya yakni terlibat dalam penyalahgunaan narkotika.

2) Faktor Rasa Ingin Tahu Dan Keinginan Untuk Mencoba Yang Besar

Maksud dari faktor ini adalah bahwasannya setiap anak pada saat anak menginjak masa remaja awal yakni pada usia 12 tahun sampai 16 tahun ${ }^{11}$ merupakan masa dimana anak tersebut memiliki rasa ingin tahu yang sangat besar terhadap suatu hal yang belum pernah dicoba, sehingga hal ini mengakibatkan anak tersebut untuk melakukannya tanpa melihat baik atau buruknya hal tersebut serta konsekuensi apa yang

11 Muchammad Al Amin, 2017, Klasifikasi Kelompok Umur Manusia Berdasarkan Analisis Dimensi Fraktal Box Counting Dari Citra Wajah Dengan Deteksi Tepi Canny, Jurnal Ilmiah Matematika, Volume 2 No.6, ISSN 2301-9115. hlm. 34. 
nantinya akan diperoleh.

3) Faktor Psikologis

Dalam faktor psikologis ini terdapat istilah egostrength (kemampuan orang menghadapi tekanan). Pada usia remaja merupakan usia dimana susah untuk mengendalikan emosi, sehingga dirinya akan mengalami tekanan. Dari adanya tekanan ini, maka anak yang terlibat dalam tindak pidana penyalahgunaan narkotika akan mengalihkannya dengan cara memakai narkotika untuk menenagkan dirinya. Mengingat narkotika sendiri memiliki efek penenang.

4) Faktor Keluarga

Faktor keluarga disini dikategorikan sebagai faktor internal, contoh dari adanya faktor keluarga ini adalah adanya kematian atau perceraian yang terjadi kepada orang tua atau keluarganya yang dianggap sebagai sosok paling penting bagi anak tersebut. Hal ini menjadikan kurangnya pengawasan terhadap sang anak. Selain itu contoh selanjutnya adalah adanya keluarga atau orang tua dari anak tersebut yang juga menjadi pengedar, pemakai atau bahkan bandar narkotika.

5) Faktor Intelegesia

Faktor ini mencankup tekait kecerdasan dan kesanggupan seseorang dalam menimbang serta mengambil keputusan. Dalam usia remaja, hal ini sangatlah rawan karena pendiriannya mudah goyah sehingga gampang untuk terhasut kedalam halhal negatif.

$$
\text { Selain faktor internal yang }
$$
dapat menyebabkan seorang anak melakukan tindak pidana penyalahgunaan narkotika, juga terdapat faktor eksternal sehingga anak melakukan tindak pidana penyalahgunaan narkotika. Berikut adalah faktor eksternal yang menyebabkan seorang anak melakukan tindak pidana narkotika.

\section{Faktor Eksternal}

Faktor eksternal merupakan faktor yang berasal dari luar diri manusia yang nantinya dapat menyebabkan timbulnya suatu kriminalitas yang dilakukan oleh seseorang yang mana dalam hal ini adalah anak sebagai pelakunya 12 . Berikut adalah contoh-contoh dari faktor eksternal yang dapat menimbulkan seorang anak melakukan tindak pidana penyalahgunaan narkotika:

1) Faktor Lingkungan

Faktor lingkungan merupakan faktor eksternal yang paling berpengaruh besar. Hal ini dikarenkan faktor ini biasanya juga dilihat dan dipengaruhi dari tingkatan pendidikan

12 Muhammad Fachri Rezza, "Analisis Kriminologis Terhadap Residivis Kejahatan Penyalahgunaan Narkotika", Jurnal Skripsi. hlm. 7. 
seseorang dan juga tingkat ekonomi seseorang. Hal ini dikarenakan nantinya dalam kehidupan masyarakat pasti terdapat suatu kelompok masyarakat yang mana didalamnya kebanyakan dari mereka memiliki tingkat pendidikan serta tingkat ekonomi yang hampir sama. Dan biasanya jika dalam suatu lingkungan tersebut terdapat pengguna, pengedar atau bandar narkotika maka secara otomatis orang-orang yang ada dalam lingkungan tersebut juga akan mengikutinya karena jika tidak mengikuti maka orang tersebut akan dikucilkan oleh golongan yang ada di lingkungan tersebut.

2. Faktor Pendidikan

Lemahnya tingkat pendidikan juga merupakan faktor yang mempengaruhi adanya 5 penyalahgunaan narkotika. Hal ini dikarenakan kurangnya sosialisasi yang biasa didapatkan pada saat di sekolah terkait pemahaman bahaya narkotika.

3. Faktor Ekonomi

Untuk faktor ekonomi sendiri dibagi lagi menjadi dua yakni tingkat ekonomi rendah dan tingkat ekonomi tinggi. Untuk tingkat ekonomi rendah biasanya anak yang melakukan dan terlibat dalam penyalahgunaan narkotika beralasan untuk memenuhi kebutuhan sehari-hari dan tergiur dengan upah yang cukup besar pada saat melakukan transaksi narkotika. Sedangkan untuk anak yang tingkat ekonominya tinggi biasannya dia hanya diberikan kebutuhan secara material yang melimpah saja oleh orang tuanya, akan tetapi tidak diberikan kasih sayang secara langsung oleh orang tuannya. Hal ini dikarenakan kedua orang tuanya sibuk dalam mencari uang sehingga tidak ada waktu bersama dengan anaknya dan menyebabkan sang anak merasa kesepian hingga akhirnya narkotika lah tempat pelarian untuk memberikan efek senang. Faktor yang keempat ini adalah sudah banyaknya peredaran gelap jual beli narkotika yang ada di Indonesia sehingga narkotika gampang untuk ditemukan dan faktor yang terakhir adalah kurangnya pengawasan pemerintah dan masyarakat terkait maraknya peredaran narkotika yang ada di Indonesia. Dari adanya faktor-faktor diatas, maka diharapkan untuk orang tua atau masyarakat yang ada di lingkungan tempat anak hidup mampu mengawasi serta menjaganya dengan baik agar tidak ada lagi kasus anak yang menyalahgunakan narkotika.

2. Pertanggungjawaban Serta Upaya Penanggulangan Yang Dapat Dilakukan Apabila Terdapat Anak Yang Melakukan Tindak Pidana Narkotika.

Pertanggungjawaban merupakan keadaan normal psikis serta kemahiran yang didalamnya terdapat tiga kemampuan yakni mampu untuk mengerti terkait makna dan akibat dari perbuatannya sendiri, mampu untuk menginsyafi bahwasannya perbuatan yang dilakukan bertentangan 
dengan ketertiban masyarakat dan mampu untuk menentukan suatu kehendak dalam berbuat 13

Adanya tindak pidana narkotika yang dilakukan oleh anak mengakibatkan suatu kecemasan serta keresahan tersendiri terhadap lingkungan sekitar. Hal ini dikarenakan takut adanya pengulangan tindak pidana narkotika yang terjadi pada anak. Disamping itu, juga terdapat banyak faktor sehingga anak tersebut melakukan tindak pidana narkotika 14 .

Dalam Undang-Undang SPPA terdapat yang namanya sistem peradilan pidana anak. Dalam Pasal 1 angka 1 Undang-Undang SPPA menyebutkan bahwa sistem peradilan pidana anak adalah keseluruhan proses penyelesaian perkara anak yang berhadapan dengan hukum, mulai dalam tahap penyelidikan sampai dengan tahap pembimbingan setelah menjalani pidana 15 . Akan tetapi dalam sistem peradilan pidana anak sendiri dalam menyelesaikan suatu perkara anak menggunakan keadilan restoratif (restorative justice). Maksud dari restorative justice ini sendiri adalah apabila terdapat suatu tindak pidana yang dilakukan

13 Eddy O.S. Hiariej, PrinsipPrinsip Hukum Pidana (Edisi Revisi), (Yogyakarta : Cahaya Atma Pustaka, 2016), hlm. 155.

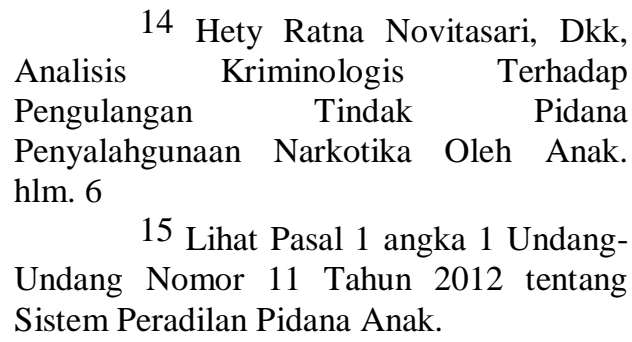

oleh anak maka penyelesaian perkaranya juga melibatkan pelaku, korban, keluarga pelaku dan/atau korban serta pihak lain yang terkait untuk bersama-sama mencari penyelesaian diluar proses peradilan yang adil dengan tujuan pemulihan kembali pada keadaan semula serta tidak adanya suatu pembalasan 16 .

Restorative justice sendiri diimplementasikan oleh Undang-Undang SPPA dengan berlakunya proses diversi 17 yang artinya pengalihan penyelesaian perkara anak dari proses peradilan pidana ke proses di luar peradilan pidana 18 sebagaimana diatur dalam Pasal 6 sampai dengan Pasal 15 Undang-Undang SPPA.

$$
\text { Selanjutnya dalam penerapan }
$$
hukum pidana terdapat dua upaya penanggulangan yang dapat diterapkan apabila terdapat anak yang melakukan tindak pidana penyalahgunaan narkotika. Upaya yang pertama adalah upaya preventif dan upaya yang kedua adalah upaya represif 19 .

\section{a. Upaya Preventif}

Upaya preventif ini merupakan suatu upaya pencegahan yang dapat

Lihat Pasal 1 angka 6 Undang-Undang SPPA.

17 R Wiyono, Sistem Peradilan Pidana Anak Di Indonesia, (Jakarta Timur : Sinar Grafika, 2019), hlm. 40.

Agus Purwadanto, Soetedjo, dkk, Kode Etik Kedokteran Indonesia, (Jakarta : Pengurus Besar Ikatan Dokter Indonesia, 2012), hlm. 2

18 Lihat Pasal 1 angka 7 Undang-Undang SPPA

19 Muhammad Fachri Rezza, Op. Cit. hlm. 8. 
dilakukan sebelum adanya tindak pidana penyalahgunaan narkotika yang dilakukan oleh anak terjadi. Upaya ini biasanya dapat berupa penyuluhan, kampanye, sosialisasi serta pendekatan kepada keluarga dan lingkungan sekitar terkait bahaya dari penyalahgunaan narkotika itu sendiri 20 . Tujuan dari adanya upaya preventif ini secara tidak langsung akan memperbaiki kondisi sosial yang ada di lingkungan sekitar $^{21}$.

\section{b. Upaya Represif}

Upaya represif merupakan upaya yang dapat dilakukan untuk membuat efek jera pada pelaku dengan cara memberikan hukuman $^{22}$. Upaya represif ini dapat dilakukan pada anak yang melakukan tindak pidana penyalahgunaan narkotika apabila dalam proses penyelesaian perkara tersebut tidak dapat dilakukan proses diversi dikarenakan ancaman pidanannya lebih dari 7 tahun dan perkara tersebut merupakan pengulangan tindak pidana 23 atau tidak adanya kesepakatan diversi antara korban dan pelaku pada perkara anak tersebut. Akan tetapi upaya represif ini merupakan jalan terakhir dalam penyelesaian perkara tindak pidana penyalahgunaan narkotika yang dilakukan oleh anak. Hal ini dikarenakan semata-mata untuk kebaikan masa depan anak tersebut.

20 Besse Patmawanti dan Kiki Yulianda, Op. Cit. hlm 27.

Cit. hlm. 9.

21 Muhammad Fachri Rezza, Op.

22 Ibid., hlm. 10.

23 Lihat Pasal 7 ayat (1) dan ayat (2) Undang-Undang SPPA.

\begin{abstract}
Pandangan hukum pidana ini berbanding terbalik dengan konsep yang ada dalam kriminologi. Apabila dalam hukum pidana, pertanggungjawaban pidana sebagaimana diatur dalam Undang-Undang SPPA dilakukan untuk memberikan efek jera. Akan tetapi dalam kriminologi pengukuman semacam ini tidak akan menimbulkan efek jera. Karena sejatinya orang yang mana dalam hal ini adalah anak yang melakukan tindak pidana narkotika tidak memerlukan penghukuman semacam ini, karena bisasaja nantinya kejadian semacam ini akan timbul kembali seiring berjalannya waktu serta adanya beberapa dukungan dari faktor internal maupun eksternal. Oleh karena itu, dalam hal ini pandangan kriminologi untuk mengatasi permasalahan ini yakni dengan cara melakukan rehabilitasi serta advoksi di lingkungan-lingkungan yang dirasa memberikan pengaruh yang negatif terhadap perkembangan anak. Sehingga dalam jangka panjang apabila advokasi tersbut dapat berjalan dengan berhasil, maka tingkat kejahatan anak yang melakukan tindak pidana terutama tindak pidana narkotika akan berkurang bahkan tidak ada.
\end{abstract}

\section{KESIMPULAN}

Berdasarkan penelitian diatas, dapat disimpulkan sebagai berikut:

1) Adanya tindak pidana penyalahgunaan narkotika yang dilakukan oleh anak secara garis besar disebabkan oleh dua 
faktor, yaitu faktor internal dan faktor eksternal.

2) Pertanggunjwaban terhadap anak yang melakukan tindak pidana penyalahgunaan narkotika sebisa mungkin dilakukan diluar proses peradilan, akan tetapi jika memang dapat diselesaikan menggunakan proses di luar peradilan maka dapat menggunakan proses di dalam peradilan.

3) Upaya-upaya yang dapat dilakukan terhadap anak yang melakukan tindak pidana penyalahgunaan narkotika adalah upaya preventif dan upaya represif.

Saran dalam penelitian ini adalah sebagai berikut:

1) Memperdalam ajaran agama yang dianut oleh masing-masing anak serta pembinaan moral dengan tujuan untuk memperkuat landasan hidup.

2) Orang tua harus lebih memperhatikan serta melakukan pengawasan terhadap pergaulan anak.

3) Bagi mahasiswa harus lebih sering melakukan pendekatan terhadap anakanak dengan cara memberikan sosialisasi atau penyuluhan terkait bahaya dari adanya penyalahgunaan narkotika

4) Lembaga serta aparat pemerintahan terkait harus lebih berkoordinasi terkait adanya tindak pidana penyalahgunaan narkotika yang dilakukan oleh anak dengan cara mengoptimalkan penyelesaian di luar proses peradilan.

\section{DAFTAR PUSTAKA \\ Buku:}

Hiariej, Eddy O.S. 2016, Prinsip-Prinsip

Hukum Pidana (Edisi Revisi). Yogyakarta: Cahaya Atma Pustaka.

Prinst, Darwan. 2003, Hukum Anak Indonesia. Bandung: PT. Citra Aditya Bakti.

Wiyono, R. 2019, Sistem Peradilan Pidana Anak Di Indonesia. Jakarta Timur: Sinar Grafika.

\section{Skripsi:}

Fadiah Idzni, "Kajian Kriminologi Terhadap Anak Yang Melakukan Tindak Pidana Narkotika (Studi Kasus di Sat. Res Narkoba Polrestabes Medan)", Skripsi, Medan: Program Studi Ilmu Hukum Strata 1 (S1) Fakultas Hukum Universitas Muhammadiyah Sumatera Utara, 2019.

Jurnal:

Besse Patmawanti dan Kiki Yulianda, "Tinjauan Kriminologi Tindak Pidana Narkotika Yang Dilakukan Oleh Anak Di Wilayah Hukum Polres 50 Kota", UNES Law Review, Volume 3, Issue 1, E-ISSN: 
2622-7045, P-ISSN: 2654-

3605, 2020.

Henny Saida Flora, “Legal Protection Of

Children In the Criminal Act

Of Narcotics", International

Journal Of Business,

Economics and law, Vol. 14,

Issue 4, December, ISSN

2289-1552, 2017

Hety Ratna Novitasari, Dkk, "Analisis

Kriminologis Terhadap

Pengulangan Tindak Pidana

Penyalahgunaan Narkotika

Oleh Anak".

Indra Kumala Sari M, "Analisis Tetang

Penyalahgunaan Narkotika

Dikalangan Siswa Ditinjau

Dari Segi Kriminologi”, Jurnal

hukum kaidah, Volume. 18,

No.1, ISSN online: 2613-9340,

ISSN offline 1412-1255. 2017.

Muchammad Al Amin, "Klasifikasi

Kelompok Umur Manusia

Berdasarkan Analisis Dimensi

Fraktal Box Counting Dari

Citra Wajah Dengan Deteksi

Tepi Canny", Jurnal Ilmiah

Matematika, Volume 2 No.6,

ISSN 2301-9115, 2017.

Muhammad Fachri Rezza, "Analisis

Kriminologis Terhadap

Residivis Kejahatan

Penyalahgunaan Narkotika",

Jurnal Skripsi.

\section{Internet:}

Berita dikutip dari:

https://denpasar.kompas.com/re ad/2020/01/15/12570781/miris-

4-anak-di bawahumur-edarkan-

narkoba-bonusnya-dikasih-

sabu?page=all (Diakses pada

30 desember 2020 Pukul 23.58

WIB). 